Marta Ulbrych

Uniwersytet Ekonomiczny, Kraków, Polska

\title{
Priorytety polityki przemyslowej w Unii Europejskiej wobec wyzwań kryzysu globalnego
}

\section{The Priorities of Industrial Policy in European Union Towards Challenges of the Global Crisis}

\begin{abstract}
Streszczenie: Obecny globalny kryzys gospodarczy podważył neoliberalne przekonanie, które w ostatnich dekadach stanowiło podwaliny poglądów zakładających ograniczenie do minimum ingerencji publicznej w gospodarkę. Tym samym polityka przemysłowa stała się ponownie tematem dyskusji. Pomimo faktu, że żyjemy w postindustrialnej epoce, w której biotechnologia, informacje i usługi są identyfikowane jako źródła wzrostu gospodarczego, nie można ignorować przemysłu wytwórczego. Ma on kluczowe znaczenie dla kształtowania zmian strukturalnych w gospodarce i generuje nowe miejsca pracy. Pożądana jest zwłaszcza aktywna polityka przemysłowa polegająca na pobudzaniu wzrostu innowacyjności oraz podnoszeniu efektywności i konkurencyjności międzynarodowej przedsiębiorstw. Takie podejście stanowi podstawowy instrument, którym rząd oddziałuje na przemiany strukturalne w przemyśle, nadając im pożądany kierunek i tempo, które ułatwią wyjście z kryzysu. Doświadczenia europejskie podkreślają potrzebę stworzenia odpowiednich warunków ramowych dla bardziej dynamicznego rozwoju przemysłu. Kluczowymi czynnikami przewagi konkurencyjnej są zasoby ludzkie i nowoczesne technologie, stąd działania powinny być ukierunkowane na promocję rozwoju kapitału ludzkiego oraz wyższe nakłady inwestycyjne na badania i rozwój.

Przedmiotem analizy jest określenie roli, znaczenia i kierunków zmian polityki przemysłowej w rozwiązywaniu aktualnych problemów gospodarczych w Unii Europejskiej. W opracowaniu zaprezentowano ewolucję oraz istotę współczesnego podejścia do polityki przemysłowej. Następnie omówiono kierunki zmian polityki przemysłowej w wybranych krajach europejskich oraz przedstawiono założenia zintegrowanego podejścia do polityki przemysłowej w Unii Europejskiej.
\end{abstract}

Abstract: The current global economic crisis has challenged the neo-liberal belief that in recent dec-
ades formed the basis of views whose assumption was to minimize public interference in the econ-
omy. Thus, industrial policy has again become a subject of discussion. Despite the fact that we live
in a post-industrial era in which biotechnology, information and services are identified as the source
of economic growth, no one can ignore the manufacturing industry. It is crucial for the formation of
structural changes in the economy and it generates new jobs. The most desirable is the active industrial
policy which is to stimulate the growth of innovation and increase the efficiency and international
competitiveness of enterprises. This approach is the essential instrument, by which the government in- 
fluences the structural changes in the industry, giving them the desired direction and pace to help overcome the crisis. The European experience emphasized the need to create the right framework conditions for a more dynamic development of the industry. The key competitive factors are human resources and modern technologies, and consequently, efforts should be directed to the promotion of human capital evolution and higher investment in research and development.

The analysis is to identify the role, importance and trends of industrial policy in dealing with the contemporary economic problems in the European Union. The paper presents the evolution and the essence of the today's approach to industrial policy. Then it is discussed the trends of industrial policy in selected European countries and described the assumptions of the integrated approach to industrial policy in the European Union.

Słowa kluczowe: polityka przemysłowa, innowacyjność, kryzys gospodarczy, niedoskonałości rynku Key words: industrial policy, innovation, economic crisis, market failures

\section{WPROWADZENIE}

Globalny kryzys finansowy, który rozpoczął się w 2008 roku podważył panujące w ostatnich dekadach przekonanie, że najlepszą polityką przemysłową jest jej brak. Polityka ta została uznana za nieuzasadnioną w latach 80. i 90. XX wieku z powodu wspierania nieefektywnych gałęzi przemysłu. Aktualne problemy społeczne i ekonomiczne większości gospodarek nie pozwalają jednak na powierzenie kwestii alokacji zasobów tylko i wyłącznie swobodnie działającym mechanizmom rynkowym. Minimalizacja obecnych niestabilności społecznych i gospodarczych wymaga między innymi bardziej aktywnego wsparcia przemysłu narodowego. Stąd jednym z wielu skutków kryzysu stał się początek nowego dyskursu publicznego wokół zasadności stosowania polityki przemysłowej.

Efektem dynamicznego rozwoju nauki i techniki ostatnich dziesięcioleci XX wieku było wkroczenie większości państw rozwiniętych w epokę postindustrialną, która charakteryzuje się zmniejszeniem znaczenia przemysłu na rzecz wzrostu sektora usług. Ponadto globalizacja i regionalizacja gospodarki światowej oraz towarzyszący im proces liberalizacji handlu i otwierania granic dla swobodnego przepływu kapitału spowodowały powstanie bardziej wydajnych centrów wytwórczych. W konsekwencji nastąpiła relokacja produkcji przemysłowej do tych części świata, w których koszty pracy są niższe. Politykę gospodarczą państwa nastawiono natomiast na budowanie innowacyjnej gospodarki kosztem rezygnacji z masowej i pracochłonnej produkcji, pozostawiając w kraju jedynie najbardziej skomplikowane etapy wytwarzania. Transformacja tradycyjnej struktury przemysłu ku przemysłom bardziej innowacyjnym i zaawansowanym technologicznie oraz postępująca serwicyzacja produkcji są oczywiście wynikiem naturalnego procesu rozwoju. Jednak priorytet budowania gospodarki opartej na wiedzy wywołuje zmiany w wielu dziedzinach gospodarki. Oddziałuje także na rynek pracy zmieniając rozmiary i strukturę popytu na pracę, co prowadzi do redukcji zatrudnienia w przemyśle. Klasyczne teorie ekonomii zakładały, że produkcja oparta na nowych technologiach rzeczywiście oszczędza pracę, ale równocześnie, dzięki wzrostowi wydajności, powoduje zwiększenie możliwości produkcyjnych. Wyższa podaż tańszych 
produktów kreuje popyt. Początkowy spadek zatrudnienia spowodowany wdrożeniem technologii zostaje zrównoważony przez przyjęcie dodatkowej siły roboczej, która jest niezbędna, by sprostać zwiększonemu poziomowi produkcji. Tymczasem rzeczywistość koryguje to założenie, ponieważ wzrost produktywności nie doprowadził bezpośrednio do wzrostu ilości miejsc pracy. Rozdźwięk pomiędzy poprawą wydajności a poziomem zatrudnienia jest najbardziej dostrzegalny w produkcji przemysłowej - zasadniczo producenci mogą wytworzyć więcej towarów, korzystając z mniejszej liczby pracowników (Rifkin 2012: 352-354).

Dodatkowo rozwój przemysłu został zakłócony w wyniku światowego kryzysu gospodarczego. W 2009 roku produkcja przemysłowa spadła w większości krajów grupy G-20, w największym stopniu w Japonii - aż o 21,3\% w stosunku do 2005 roku. Analizując zmiany w okresie 2005-2011 stosunkowo szybki rozwój można zaobserwować w Indiach i Korei Południowej, a także w nieco mniejszym stopniu w Turcji, Indonezji, Rosji i Brazylii. Natomiast produkcja przemysłowa w 2011 roku w Republice Południowej Afryki, Australii, Unii Europejskiej i Stanach Zjednoczonych była na zbliżonym poziomie do 2005 roku (European Commission 2012: 74-75). Równocześnie w tych krajach odnotowano najniższe stopy wzrostu PKB spośród wszystkich gospodarek G-20.

Załamanie tempa wzrostu gospodarczego, presja konkurencji międzynarodowej oraz wewnętrzne problemy społeczne z bezrobociem na czele sprawiają, że prowadzenie aktywnej polityki przemysłowej stało się sprawą oczywistą i powszechnie stosowaną. Funkcja polityki przemysłowej pozostaje niezmienna i oznacza ogół przedsięwzięć dotyczących procesów gospodarczych zachodzących w przemyśle podejmowanych przez władzę centralną. Samo jednak pojęcie i jego instrumenty są różnie definiowane w poszczególnych krajach. Nasuwa się zatem pytanie, jaki zakres stosowania polityki przemysłowej jest obecnie najbardziej efektywny.

Celem opracowania jest określenie roli i znaczenia polityki przemysłowej w rozwiązywaniu współczesnych problemów gospodarczych w Unii Europejskiej wobec narastających negatywnych tendencji w gospodarce światowej. Tak zarysowany problem badawczy wymaga usystematyzowania teoretycznych przesłanek stosowania polityki przemysłowej oraz określenia kierunków jej zmian w UE i wybranych krajach członkowskich. Do zrealizowania założeń posłużono się analizą literatury przedmiotu polskich i zagranicznych autorów oraz dokumentów źródłowych.

\section{ROLA POLITYKI PRZEMYSŁOWEJ WE WSPÓŁCZESNEJ GOSPODARCE}

Ciągłe zaostrzanie się konkurencji w ujęciu globalnym rodzi potrzebę redefinicji podejścia do polityki przemysłowej. Na rynkach światowych, obok przedsiębiorstw o wysokiej pozycji konkurencyjnej pochodzących z krajów rozwiniętych, pojawiają się nowi silni producenci z gospodarek wschodzących. Następuje wzrost liczby przedsiębiorstw o niskich kosztach produkcji, rosnącym poziomie kwalifikacji pracowników i systematycznie poprawiających się innych czynnikach decydujących o konkurencyjności. Dotychczas w polityce przemysłowej większości krajów rozwiniętych dominowało stanowisko neoliberalne, które 
zakładało, że gospodarka będzie rozwijała się optymalnie poprzez działanie nieskrępowanych sił wolnorynkowych. Kraje nowo uprzemysłowione, które cechują się m.in. dynamicznym rozwojem przemysłów zaawansowanych technologii, skorzystały natomiast z posiadanych zasobów taniej siły roboczej i poprzez odpowiednią politykę stworzyły zachęty dla inwestorów oraz wsparły działalność eksportową, co wywołało dynamiczny wzrost PKB. W gospodarkach tych postępowano w myśl modelu spóźnionego rozwoju gospodarczego Gerschenkrona, który zakłada, że im bardziej dany kraj jest opóźniony w rozwoju gospodarczym, tym więcej interwencjonizmu państwowego potrzebuje, by nastąpił wzrost (Breznitz 2007: 12).

Przesłanki stosowania polityki przemysłowej są oparte na założeniu, że siły wolnorynkowe nie są w stanie osiągnąć optymalnych wyników. Wówczas niezbędna jest interwencja państwa, które koryguje niedoskonałości rynku i wspiera industrializację, a przez to generuje nowe miejsca pracy. Zapobiega tym samym sytuacji, kiedy podmioty rynkowe nie są w stanie osiągnąć potencjalnej wydajności w sensie statycznym i dynamicznym (Klamut 2006: 246-247). Niedoskonałości w sensie statycznym opisują okoliczności, kiedy przedsiębiorstwo zadawala się niższym poziomem produkcji i nie w pełnym zakresie wykorzystuje swoje zdolności produkcyjne. Z kolei niedoskonałości w sensie dynamicznym odnoszą się do tych przypadków, w których przedsiębiorstwo nie przeznacza wystarczająco dużo środków na badania i rozwój potencjału produkcyjnego. W konsekwencji nie osiąga możliwych korzyści wynikających z bardziej wydajnej i tańszej produkcji, co może utrudnić sprostanie konkurencji na rynku globalnym. Kluczowym argumentem za stosowaniem polityki przemysłowej jest zapobieganie dynamicznym skutkom niedoskonałości rynku poprzez finansowanie określonych kierunków badań naukowych.

Aktualne tendencje w polityce przemysłowej mają charakter horyzontalny, czyli ich celem jest oddziaływanie na przemysł poprzez stałe podnoszenie jakości warunków ramowych prowadzenia działalności przemysłowej. Podejmowane inicjatywy są wspólne dla wszystkich sektorów i powinny prowadzić do podnoszenia innowacyjności i poziomu zastosowanych technologii, poprawy jakości kapitału ludzkiego i dostosowania jego struktury do potrzeb rynkowych. Obejmują one także usuwanie barier prawnych i administracyjnych, które utrudniają rozwój przedsiębiorstw (Ministerstwo Gospodarki 2007: 3). Natomiast tradycyjna sektorowa polityka ma obecnie zastosowanie głównie w przypadku branż o strategicznym znaczeniu dla rozwoju i bezpieczeństwa państwa.

Współcześnie postęp techniczny i innowacyjność mają strategiczne znaczenie, stając się narzędziem wzrostu konkurencyjności gospodarek. Głównym celem polityki przemysłowej jest stymulowanie wzrostu gospodarczego poprzez unowocześnianie, racjonalizację i intensyfikację procesów wytwórczych. Zadanie państwa polega na czynnym zaangażowaniu się w sferę nauki i rozwoju w celu szybszego transferu rezultatów badań do praktyki życia gospodarczego i społecznego. Niezbędne wydaje się aktywne podejście do polityki przemysłowej, czyli takie oddziaływanie państwa na gospodarkę, którego rezultatem jest pobudzanie wzrostu efektywności produkcji przemysłowej i poprawa konkurencyjności towarów zawierających duży wkład wartości dodanej (Nagórny 2011: 476-477).

Na skutek wzrastającej współzależności krajów w gospodarce światowej oraz rozbudowy globalnych sieci produkcji i rozproszenia procesu produkcyjnego, maleje rola państwa 
narodowego na korzyść władz regionalnych i lokalnych w zakresie pobudzania wzrostu gospodarczego. Zjawisko to przyczyniło się do redefinicji podejścia do polityki przemysłowej, podczas gdy tradycyjnie oznaczała ona bezpośrednią interwencję organów centralnych w rynek poprzez wybieranie tzw. zwycięzców i wspieranie rozwoju poszczególnych sektorów. Obecnie nowe podejście polega na jej formułowaniu i implementacji „od dołu” (from the bottom), czyli na poziomie lokalnym i regionalnym. Polityka przemysłowa opisuje tym samym różne działania władz publicznych mające na celu odpowiednie nakierowanie i kontrolowanie procesu transformacji strukturalnej w gospodarce (Bianchi 2006: 3-4). W tym kontekście należy także podkreślić przekrojowy charakter polityki przemysłowej. Istnieje potrzeba synergii i komplementarności pomiędzy różnymi obszarami polityki, które wywierają wpływ na przemysł - w szczególności konkurencji, handlowym, innowacji, regionalnym, energetycznym oraz rozwoju kapitału ludzkiego i ochrony środowiska.

KIERUNKI ZMIAN POLITYKI PRZEMYSŁOWEJ W WYBRANYCH KRAJACH EUROPEJSKICH

Analiza zmian produkcji przemysłowej w Unii Europejskiej pokazuje, że zarówno pod względem udziału w tworzeniu PKB, jak i zatrudnienia rola przemysłu maleje na korzyść usług. Udział przemysłu w tworzeniu PKB systematycznie spada od lat 80. XX wieku, w 1980 roku wynosił on 25,5\%. Ta negatywna tendencja jest szczególnie widoczna od 1990 r., kiedy wskaźnik ten wynosił jeszcze $22,4 \%$ PKB i ulegał regularnej redukcji do poziomu 15,5\% w 2011 roku (Aiginger, Sieber 2005; Tajani 2012). Równolegle spada także poziom zatrudnienia w przemyśle, w ciągu ostatniej dekady o ponad 3 punkty procentowe (wyk. 1). Pomimo tych tendencji, nikt nie kwestionuje potrzeby silnej bazy przemysłowej w Europie, która ma kluczowe znaczenie w zakresie przekształceń strukturalnych gospodarki. Branże przemysłowe pozostają głównym motorem innowacji i postępu ( $80 \%$ prywatnych wydatków sektora $\mathrm{B}+\mathrm{R}$ w Europie dokonywanych jest w ramach produkcji przemysłowej), tworzenia miejsc pracy (każde nowe stanowisko w przemyśle kreuje dodatkowe w usługach) oraz eksportu (75\% unijnego eksportu stanowi produkcja przemysłowa) (Tajani 2012).

Wyniki w zakresie dynamiki produkcji przemysłowej ponownie podkreślają negatywne skutki kryzysu gospodarczego, który silnie uderzył w europejski przemysł wytwórczy (wyk. 2). W 2009 roku produkcja przemysłowa spadła we wszystkich krajach członkowskich Unii Europejskiej, powracając na ścieżkę wzrostu w następnych latach. Jedynie w przypadku Grecji, Hiszpanii i Portugalii, czyli gospodarek szczególnie dotkniętych kryzysem, nie odnotowano poprawy w 2011 roku. Na szczególną uwagę zasługuje RFN ze względu na fakt, że jest najbardziej uprzemysłowionym krajem europejskim, 25\% całkowitej wartości dodanej w sektorach produkcyjnych wszystkich państw członkowskich jest dostarczane przez przemysł niemiecki (dane dla 2009 roku). Wartość ta jest w zasadzie stała w ostatnim dziesięcioleciu, w 2000 roku wynosiła ona 25,3\%. Przeciwnie jest w przypadku Wielkiej Brytanii, w której następuje systematyczny i zauważalny spadek produkcji przemysłowej - o ile w 2000 roku wytwarzała ona jeszcze 17\% wartości dodanej UE, tak w 2009 jedynie 11,1\% (Federal Ministry of Economics and Technology 2012). 


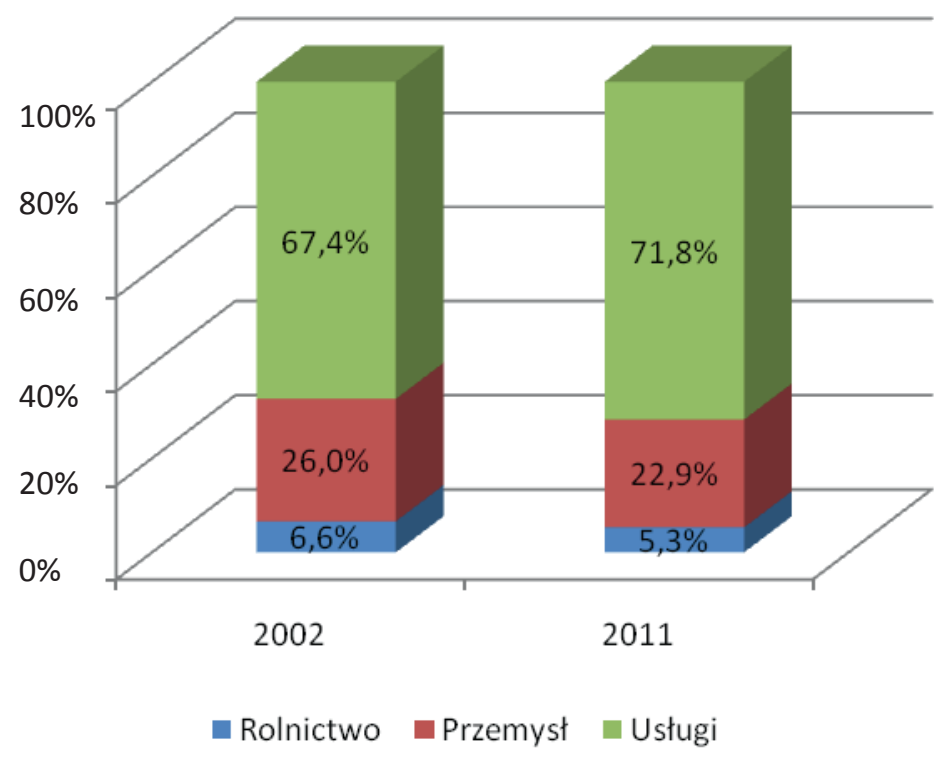

Wyk. 1. Zatrudnienie w Unii Europejskiej wg sektorów w \% ogółu zatrudnionych w 2002 i 2011 r.

Źródło: opracowanie własne na podstawie danych Eurostatu. (29.11.2012, 29). Employment Growth and Activity Branches. Pozyskano z http://appsso.eurostat.ec.europa.eu

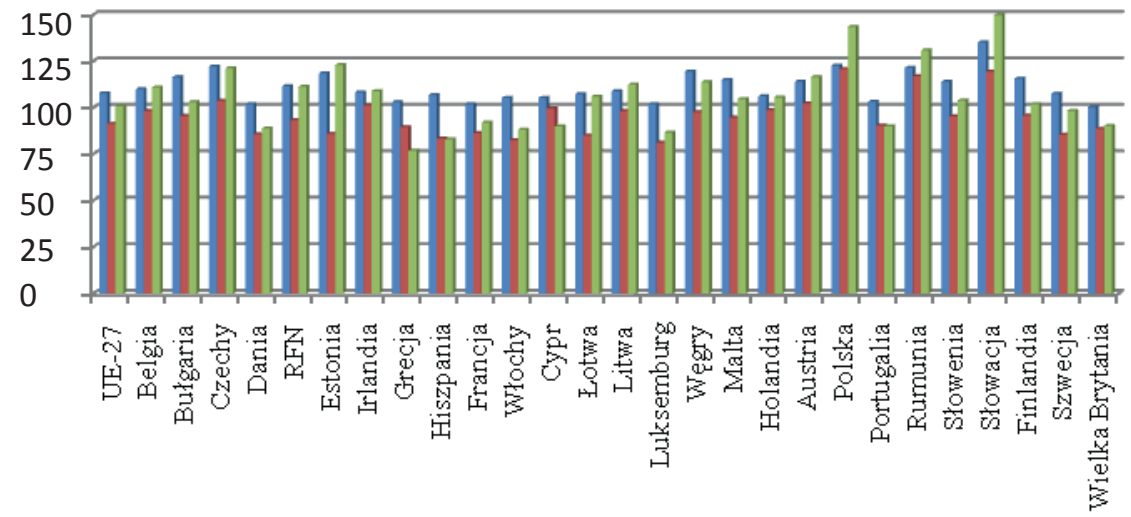

— $2007 \quad 2009-2011$

Wyk. 2. Dynamika produkcji przemysłowej w krajach Unii Europejskiej $(2005=100)$

Źródło: opracowanie własne na podstawie danych Eurostatu (29.11.2012) Industry Production Index. Pozyskano z http://appsso.eurostat.ec.europa.eu 
Poszczególne kraje członkowskie reprezentują odmienne podejście do polityki przemysłowej i stosują różne instrumenty wsparcia. Analizie zostanie poddany przypadek Finlandii i Irlandii. Obie gospodarki wykazywały wysoką stopę wzrostu w latach 90. XX wieku, co było wsparte działaniami w ramach polityki przemysłowej. Obecnie ich struktura przemysłu zdominowana jest przez sektor zaawansowanych technologii. Kraje te obrały jednak inne priorytety i kierunki rozwoju, co w konsekwencji przełożyło się na kondycje ich gospodarek dotkniętych kryzysem.

\section{PRZYKŁAD FinLANDII I IRLANDII}

Finlandia stanowi przykład udanego budowania gospodarki opartej na wiedzy, do którego przyczynił się rozwój przemysłu zaawansowanej technologii. Od połowy lat 90 . XX wieku rosła rola tej branży, by dziesięć lat później stanowić $1 / 5$ krajowego eksportu. Jednym ze źródeł napędzających fińską gospodarkę pozostaje przemysł high-tech, chociaż jego udział w całkowitym eksporcie w 2011 roku zmniejszył się o połowę w stosunku do 2007 (wyk. 3). Śledząc rozwój gospodarczy Finlandii można wyodrębnić trzy zasadnicze etapy, które charakteryzują się klasyczną ewolucją poprzez przenoszenie przewag komparatywnych od towarów pracochłonnych i surowcochłonnych, przez kapitałochłonne, po produkty odznaczające się wysokim stopniem innowacyjności (Stachowiak 2009: 122-126). Pierwszy etap - gospodarki opartej na zasobach i surowcach - rozpoczął się w połowie XIX wieku i trwał do lat 30. XX wieku. Wówczas podstawowymi czynnikami wytwórczymi były praca oraz drewno i systemy wodne. Skuteczne ich zaangażowanie w przemyśle pozwoliło rozwinąć eksport drewna i produktów drzewnych. Państwo nie pozostawało bierne budując sieci infrastrukturalne oraz system instytucjonalny w odniesieniu do systemu finansowego i edukacji. Druga faza rozwoju, kapitałochłonnej produkcji obejmuje okres powojenny, który także charakteryzował się współpracą państwa i przemysłu w zakresie stwarzania warunków zachęcających do inwestycji. Stosowano szereg zachęt i ulg podatkowych oraz odpowiednią politykę kursową, która miała poprawić konkurencyjność cenową eksportu. W tym czasie dokonywano szeregu inwestycji w systemy produkcji związane z obróbką i przetwarzaniem drewna. Zaczął rozwijać się także przemysł elektroniczny dostarczając technologie, które umożliwiały automatyzację produkcji i przesył informacji. Początki transformacji fińskiej gospodarki w kierunku modelu opartego na wiedzy sięgają przełomu lat 80. i 90. XX wieku. Recesja, która najsilniej dotknęła Finlandię w latach 1991-1993, zmotywowała władze fińskie do podjęcia radykalnych reform gospodarczych. Wysiłki i inwestycje zostały skierowane na rozwój edukacji i badań, a wzrost nakładów w tych obszarach umożliwił dynamiczny rozwój sektora usług i zaawansowanej technologii, szczególnie teleinformatycznej. System ten zaczął szybko przynosić pozytywne efekty napędzając wzrost gospodarczy kraju i poprawiając jego międzynarodową pozycję konkurencyjną. Gospodarka fińska, podobnie jak inne gospodarki europejskie, zwolniła w 2008 roku, a w kolejnym odnotowała spadek PKB aż o 8,5\%. Szybki powrót na ścieżkę wzrostu w 2010 roku podkreśla solidne podstawy gospodarki fińskiej. Finlandia podtrzymała dotychczasowy kierunek polityki zorientowanej 
na innowacje i rozwijanie nowych technologii. Wydatki na badania i rozwój, których poziom powyżej 3,5\% PKB jest najwyższy wśród krajów UE, wciąż stanowią element oddziaływania państwa na tworzenie i ulepszanie kluczowych zasobów, takich jak wiedza i kreatywność. Dynamiczny rozwój gospodarki fińskiej był możliwy dzięki wypracowaniu ram instytucjonalnych sprzyjających prowadzeniu działalności gospodarczej. Niezmiernie istotne jest partnerstwo, które znalazło swój wyraz w zaangażowaniu zarówno państwa, jak i przedsiębiorców w proces budowy innowacyjnej gospodarki. Ponadto kraj ten odznacza się wysokim poziomem kapitału społecznego, a rozkwit rodzimej produkcji prowadzi do wzrostu spójności społeczno-gospodarczej.

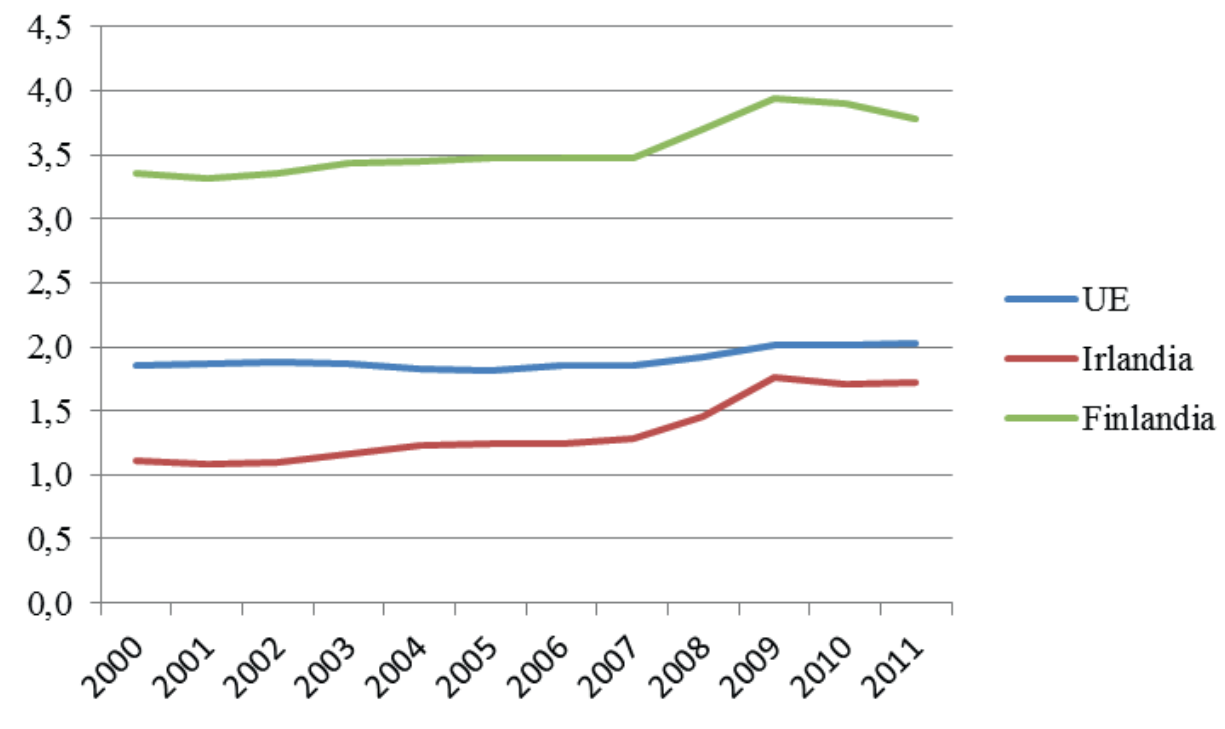

Wyk. 3. Udział wyrobów high-tech w całkowitym eksporcie Unii Europejskiej, Finlandii i Irlandii w latach 2007-2011

Źródło: opracowanie własne na podstawie danych Eurostatu (29.11.2012). Total high-tech trade in million euro and as a percentage of total (from 2007, SITC Rev. 4). Pozyskano z http://appsso.eurostat.ec.europa.eu

Gwałtowny wzrost celtyckiego tygrysa w latach 90. XX wieku ma nieco inne podstawy. Irlandia przystępując do Europejskiej Wspólnoty Gospodarczej w 1973 roku była krajem relatywnie biednym o słabej infrastrukturze. Zdołała jednak w ciągu 15 lat zbudować konkurencyjną, proeksportowo zorientowaną i wysoko rozwiniętą gospodarkę. Pierwsze działania na rzecz otwierania gospodarki, po okresie substytucji importu, zapoczątkowano w latach 60 . XX wieku. Główną jednak przyczyną integracji z rynkiem globalnym była realizacja polityki zainicjowanej Programem Narodowej Odbudowy, który obejmował lata 1986-1990 (Talar 2007: 252-253). Do głównych działań, jakie wówczas podjęto należy zaliczyć tworzenie sprzyjających i stabilnych warunków technicznych i prawnych dla działalności prywatnych przedsiębiorstw. Służyło to także poprawie atrakcyjności Irlandii jako miejsca lokalizacji dla zagranicznych inwestycji bezpośrednich (BIZ). Zasadniczymi bodźcami, które przyciągały 
BIZ były ulgi podatkowe, rozwój wykwalifikowanej kadry oraz poprawa infrastruktury technicznej, możliwa m.in. dzięki efektywnej absorpcji środków finansowych w ramach funduszy UE. Inwestycje zagraniczne koncentrowały się w dziedzinach powiązanych z najnowszą technologią: przemysł farmaceutyczny, informatyczny i elektroniczny oraz usługi finansowe. Konsekwencją obranego kierunku polityki przemysłowej są zmiany strukturalne przemysłu i struktury eksportu. Motorem szybkiego wzrostu gospodarczego okazał się właśnie eksport, w tym przede wszystkim z sektorów wysokiej techniki. Udział wyrobów high-tech, po załamaniu w 2010 roku, ponownie wynosi blisko 30\% całkowitego eksportu Irlandii (wyk. 3). Kraj ten zawdzięcza swój sukces przede wszystkim proeksportowemu charakterowi BIZ oraz ich umiejętnemu ukierunkowaniu do sektorów wysokiej technologii. Przyjęty otwarty model rozwoju spowodował, że gospodarka irlandzka silnie odczuła skutki kryzysu już w 2008 roku i latach następnych. Główne przyczyny recesji wynikały z niskiego poziomu innowacji przemysłu krajowego oraz braku spójności społecznej na skutek dużego rozwarstwienia dochodowego społeczeństwa (Bianchi, Labory 2011: 115-118). Reakcją rządu irlandzkiego na spadek wzrostu gospodarczego było przyjęcie w 2008 roku dokumentu Building Ireland's Smart Economy. Określa on cele polityki przemysłowej na kolejne 5 lat, a wśród nich: kontynuację stwarzania zachęt dla inwestorów zagranicznych, dalszą promocję sektora high-tech poprzez niższe podatki i redukcję płac oraz budowę gospodarki przyjaznej środowisku.

Porównując doświadczenia fińskie i irlandzkie należy zauważyć, że o ile w pierwszym przypadku strategia zorientowana jest na inwestycje w przyszłość, tak w drugim dominują bardziej bieżące rozwiązania, co jest widoczne chociażby w poziomie wydatków na badania i rozwój (wyk. 4).

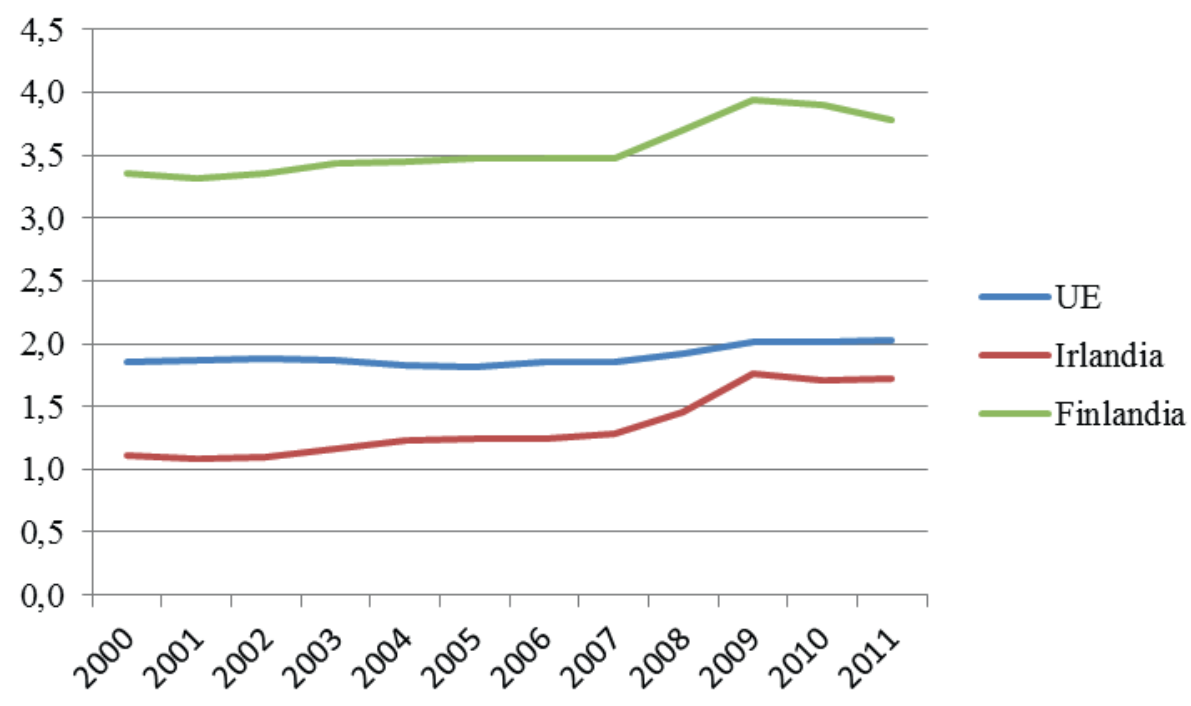

Wyk. 4. Wydatki na badania i rozwój w Unii Europejskiej, Finlandii i Irlandii w latach 2000-2011 (\% PKB)

Źródło: pracowanie własne na podstawie danych Eurostatu (29.11.2012). Total intramural R\&D expenditure (GERD) by sectors of performance. Pozyskano z http://appsso.eurostat.ec.europa.eu 
Przemysł w krajach europejskich przechodzi istotne zmiany i staje w obliczu kolejnych wyzwań. Konkurowanie z krajami o niskich kosztach pracy jest skazane na porażkę, dlatego należy skierować wysiłki na skuteczne wykorzystanie wiedzy przez przemysł, tworzenie przewag konkurencyjnych w oparciu o innowacje i kreatywność oferowanych produktów. W tym celu niezbędne jest stwarzanie przesłanek zachęcających do rozwoju przemysłu. Wydaje się, że optymalne rozwiązanie w tym zakresie może zostać osiągnięte na poziomie jednolitego rynku, czyli wymagane jest zintegrowane podejście do polityki przemysłowej w Unii Europejskiej oraz solidarna i konsekwentna implementacja jego zasad przez wszystkie kraje członkowskie. Brak skoordynowanych działań i inicjatywy podejmowane często z punktu widzenia partykularnych interesów krajów członkowskich mogą prowadzić do większej polaryzacji rozwoju.

\section{ZINTEGROWANE PODEJŚCIE DO POLITYKI PRZEMYSŁOWEJ W UNII EUROPEJSKIEJ}

Europejska polityka przemysłowa jest ściśle związana z ogólną polityką społeczno-gospodarczą, a na jej treść składają się także inicjatywy podejmowane w obszarach innych polityk. Większość jej działań wciąż realizuje się w ramach kompetencji państw członkowskich. Śledząc rozwój polityki przemysłowej w UE można zasadniczo wyróżnić 3 etapy oraz towarzyszące im działania, dźwignie rozwoju przemysłu oraz podejście do sposobu wsparcia przedsiębiorstw (tab. 1). Głównymi elementami rozwoju przemysłu są zasoby i reguły (Bianchi, Labory 2011: 94). Pierwsze z nich uwzględniają wiedzę, kapitał ludzki, ale także surowce i infrastrukturę. Drugie natomiast odnoszą się zarówno do zasad społecznych, jak i przepisów prawnych, które determinują chociażby dostęp do edukacji, czy procedurę zakładania działalności gospodarczej. Kraje dysponują różnymi zasobami oraz wypracowują odmienne regulacje, które określają możliwości organizacji produkcji i ścieżkę rozwoju przemysłu. Niejednorodne zasoby i reguły stanowią dźwignie, które decydenci mogą aktywnie wykorzystywać promując rozwój przemysłu.

Pierwszy etap ewolucji polityki przemysłowej w UE obejmuje lata 70. i 80. XX wieku. Wówczas nie miała ona charakteru wspólnotowego i pozostawała w gestii poszczególnych państw członkowskich. W traktatach założycielskich nie ma bezpośredniego odwołania do polityki przemysłowej. Komisja europejska dostrzegła jednak jej ważność powołując w 1967 roku Dyrekcję Generalną ds. Polityki przemysłowej. Powierzyła jej koordynację narodowych polityk i monitorowanie konkurencji zewnętrznej oraz współdziałanie w poprawie produktywności europejskiego przemysłu i utrzymywaniu wysokiego poziomu zatrudnienia. Reguły, na których opierała się wtedy polityka przemysłowa stanowiły wynikową regulacji w ramach polityki handlowej i konkurencji. Nacisk położono także na niezbędne dla rozwoju zasoby (kapitał ludzki, kapitał finansowy i surowce) rozszerzając zakres zasad gwarantujących ich dostępność. W tym okresie dominowało podejście interwencjonistyczne i selektywne do polityki przemysłowej. Charakteryzowało się ono wspieraniem schyłkowych oraz wybranych gałęzi przemysłu, czy przedsiębiorstw - tzw. liderów krajowych w branżach 
uznanych za istotne dla rozwoju gospodarki narodowej. Chroniono także nowo powstające gałęzie przed konkurencją zewnętrzną w początkowym etapie ich rozwoju.

Tab. 1. Etapy ewolucji europejskiej polityki przemysłowej

\begin{tabular}{|c|c|c|c|}
\hline Wyróżnienie & $\begin{array}{c}\text { ETAP I } \\
1970-1980\end{array}$ & $\begin{array}{c}\text { ETAP II } \\
\text { Bangemann }\end{array}$ & $\begin{array}{c}\text { ETAP III } \\
\text { Nowa polityka }\end{array}$ \\
\hline Działania & $\begin{array}{l}\text { subsydia dla schyłko- } \\
\text { wych gałęzi przemysłu } \\
\text { wspieranie liderów } \\
\text { krajowych ochrona } \\
\text { początkujących branż } \\
\text { przemysłowych (infant } \\
\text { industry) }\end{array}$ & \begin{tabular}{|l|} 
działanie w kontekście \\
tworzenia konkurencyjnego \\
otoczenia (regulacje anty- \\
monopolowe na szczeblu \\
terytorialnym) \\
rozwój nowych przemy- \\
słów (opartych na inno- \\
wacjach i nowoczesnych \\
technologiach)
\end{tabular} & $\begin{array}{l}\text { zapewnienie sprawiedliwych } \\
\text { reguł } \\
\text { rozwój nowych przemysłów } \\
\text { (opartych na wiedzy) } \\
\text { innowacje poprzez tworzenie } \\
\text { i akumulację wiedzy } \\
\text { złożone interakcje, sieci }\end{array}$ \\
\hline Dźwignie & $\begin{array}{l}\text { zasoby } \\
\text { reguły }\end{array}$ & $\begin{array}{l}\text { zasoby } \\
\text { reguły } \\
\text { innowacje } \\
\text { terytorium }\end{array}$ & $\begin{array}{l}\text { zasoby } \\
\text { reguły } \\
\text { innowacje } \\
\text { terytorium }\end{array}$ \\
\hline Podejście & tradycyjne, sektorowe & horyzontalne & $\begin{array}{l}\text { dynamiczne: nacisk } \\
\text { na rozwój zrównoważony }\end{array}$ \\
\hline
\end{tabular}

Źródło: Bianchi, Labory 2011. Industrial Policy after the Crisis. Seizing the Future, Edward Elgar Publishing, Cheltenham 2011, s. 134

Druga faza różniła się zasadniczo od poprzedniej. Przede wszystkim w tym czasie podjęto pierwsze zbiorowe działania w celu wspierania rozwoju przemysłu wraz z programem budowy jednolitego rynku wewnętrznego, zawartego w Białej Księdze z 1985 roku. Paragraf pierwszy artykułu 130 stanowi, że „celem Wspólnoty jest wzmocnienie baz naukowych i technologicznych przemysłu europejskiego oraz popieranie rozwoju jego konkurencyjności międzynarodowej” (The Single European Act 1986: 15). Inicjatywy realizowane w celu utworzenia rynku wewnętrznego stanowiły istotny bodziec dla polityki przemysłowej i silnie akcentowały potrzebę określenia reguł zabezpieczających uczciwą konkurencję. Zdolność rządów do selektywnego wspierania ich przemysłu została ograniczona, a wcześniej chronione sektory zostały częściowo zliberalizowane. Podstawy traktatowe polityka przemysłowa UE uzyskała jednak dopiero wraz z Traktatem z Maastricht ${ }^{1}$, który powtórzył potrzebę zapewnienia warunków niezbędnych dla rozwoju przemysłu. Podkreślił także rolę badań i innowacji w kształtowaniu konkurencyjności gospodarki. Innym dokumentem koncentrującym się na innowacjach i tworzeniu społeczeństwa informacyjnego był raport komisarza M. Bangemanna pt. Europa i globalne społeczeństwo informacyjne z 1994 roku. Zalecenia te spowodowały zmianę podejścia do polityki przemysłowej, czyli odejście od interwencji bezpośredniej na korzyść wsparcia horyzontalnego. Podczas tego etapu zidentyfikowano

1 Traktat z Maastricht w tytule XIII: Przemyst wymienia cele warunkujące poprawę konkurencyjności przemysłu europejskiego: przyspieszenie dostosowań do zmian strukturalnych, wspieranie środowiska sprzyjającego przedsiębiorczości, wspieranie współpracy między przedsiębiorstwami, zachęcanie do lepszego wykorzystania potencjału przemysłowego polityk innowacyjnych, badań i rozwoju techniki. 
także dwie dodatkowe dźwignie rozwoju przemysłu, czyli innowacje jako motor rozwoju europejskich firm oraz terytorium jako obszar akumulacji wiedzy i wymiany doświadczeń.

Formułowanie zasad trzeciego etapu rozwoju europejskiej polityki przemysłowej było reakcją na gwałtowny wzrost wydajności w USA od połowy lat 90 . XX wieku, związany z zastosowaniem technologii informacyjnych. W wyniku dyskusji nad kierunkami rozwoju gospodarczego Europy przyjęto Strategię Lizbońską w 2000 roku. Zakładała ona, że celem Unii Europejskiej jest sprostanie konkurencji międzynarodowej dzięki dynamicznemu rozwojowi gospodarki opartej na wiedzy do 2010 roku. W ramach Strategii została wypracowana formuła nowej polityki przemysłowej, opartej na intensyfikacji procesów innowacyjnych. Celem Komunikatu Komisji z 2005 roku było wzmocnienie sektora przemysłowego Unii Europejskiej poprzez stworzenie bardziej zintegrowanego podejścia do polityki przemysłowej rozszerzającego i uzupełniającego dotychczasowe ramy (COM (2005) 474). W dokumencie wskazano kierunek zmian, które miały doprowadzić do wzrostu konkurencyjności przemysłu, tworzenia nowych miejsc pracy i zwiększenia wydatków na badania i rozwój poprzez przyciągnięcie inwestycji w tym zakresie. Innym wyzwaniem, w obliczu którego stanęła Unia było poszerzenie o kraje Europy Środkowej i Wschodniej. W 2002 roku Komisja Europejska przyjęła dokument w sprawie Polityki przemysłowej w rozszerzonej Europie. Podkreśliła w nim znaczne różnice pomiędzy strukturą przemysłu wytwórczego w państwach członkowskich oraz w krajach kandydujących. Dwa lata później ustaliła główne kierunki działania polityki przemysłowej w komunikacie pt. Wspieranie przemian strukturalnych: polityka przemysłowa dla rozszerzonej Europy. Zostały wówczas wyróżnione trzy obszary działań dla wspierania zmian w europejskim przemyśle: lepsze stanowienie prawa poprzez dostosowanie przepisów do potrzeb przedsiębiorstw, współdziałanie z innymi politykami dla wspólnego celu poprawy wzrostu wydajności i lepszego wykorzystania wiedzy oraz potrzebę uwzględniania specyfiki poszczególnych sektorów w realizacji środków horyzontalnych (COM (2004) 274). Wypracowywana przez lata europejska polityka przemysłowa została ostatecznie ustalona, a na jej treść składają się działania podejmowane w różnych obszarach bezpośrednio i pośrednio wpływających na stworzenie środowiska korzystnego dla rozwoju przemysłu. Zasadniczo działania i dźwignie wspierające rozwój przemysłu są podobne do tych podejmowanych $\mathrm{w}$ trakcie poprzedniego etapu ewolucji polityki. Charakteryzują się one jednak bardziej dynamicznym podejściem rozpatrywanym w aspekcie zrównoważonego rozwoju, który dąży do równowagi między różnymi obszarami: gospodarczym, społecznym i środowiskowym. Podkreśla się także rolę sieci, które poprzez gromadzenie zasobów i wiedzy oraz wspieranie współpracy między przedsiębiorstwami, organami publicznymi i uniwersytetami ulepszają innowacje i poprawiają konkurencyjność przemysłu.

Aktualna debata wokół polityki przemysłowej została wywołana następstwami kryzysu z 2008 roku. Niski poziom wzrostu gospodarczego krajów europejskich oraz rosnąca liczba interwencji władz publicznych stały się inspiracją do bieżącego dyskursu, który został włączony do Strategii Europa 2020. Przyjęta w 2010 roku Strategia na rzecz inteligentnego i zrównoważonego rozwoju sprzyjajacego właczeniu społecznemu stanowi właśnie odpowiedź na kryzys gospodarczy, nasilającą się konkurencję międzynarodową, starzenie się społeczeństwa i zmiany klimatyczne. Źródłem wzrostu gospodarczego ma być 
gospodarka oparta na wiedzy, przyjazna środowisku naturalnemu i efektywnie wykorzystująca dostępne zasoby. Dla realizacji przyjętych priorytetów przygotowano siedem inicjatyw, w tym także projekt zatytułowany Zintegrowana polityka przemysłowa w erze globalizacji. Konkurencyjność i zrównoważony rozwój na pierwszym planie. Jego celem jest pobudzenie wzrostu gospodarczego i tworzenie miejsc pracy poprzez utrzymanie oraz wsparcie silnej, zróżnicowanej i niskoemisyjnej bazy przemysłowej. Do kluczowych elementów, które zostały zaproponowane w kontekście tych założeń, należy zaliczyć (COM (2010) 614: 6-7):

- połączenie bazy horyzontalnej i zastosowania sektorowego, czyli stosowanie indywidualnego podejścia do wszystkich sektorów. Głównym wyzwaniem jest rozwinięcie i wprowadzenie kluczowych technologii wspomagających, które mogą stanowić podstawę dla szeregu nowych produktów i usług;

- uwzględnianie całego łańcucha wartości i dostaw: od dostępu do energii i surowców, poprzez infrastrukturę, aż po usługi posprzedażowe i recykling materiałów. Niektóre części tego łańcucha znajdują się poza Europą, dlatego istotny jest także kontekst globalny;

- regularne informowanie przez Komisję o polityce w zakresie konkurencyjności i polityce przemysłowej UE, jej państw członkowskich oraz efektach tych polityk.

Koncepcja zintegrowanej polityki oznacza, że obejmuje ona współdziałanie różnych polityk Unii Europejskiej oraz podkreśla konieczność współpracy i koordynacji działań między Komisją Europejską i państwami członkowskimi. Zasadnicze zadania, jakie postawiono przed europejską polityką przemysłową, skupiają się na: stworzeniu korzystnego otoczenia dla działania małych i średnich przedsiębiorstw; koordynacji działań w ramach edukacji, badań i rozwoju; kształtowaniu spójności ekonomicznej i społecznej UE; modernizacji przemysłu poprzez odpowiednie gospodarowanie zasobami efektywności energetycznej i niskoemisyjności oraz adaptacji przemysłu do zmian strukturalnych w gospodarce światowej.

Priorytetowe znaczenie przemysłu dla wzrostu gospodarki UE i wyjścia z kryzysu zostało także podkreślone w przyjętej w październiku 2012 roku strategii reindustrializacji UE. Zakłada ona zwiększenie udziału produkcji przemysłowej w tworzeniu unijnego PKB do 20\% w 2020 roku (w 2011 wynosił on 15,5\%). Wzmocnienie polityki przemysłowej powinno oprzeć się na czterech filarach, którymi są: inwestycje w innowacje, poprawa funkcjonowania rynku wewnętrznego, zwiększenie dostępu do kapitału oraz promowanie rozwoju kapitału ludzkiego. Zapewnienie odpowiednich warunków dla inwestycji jest szczególnie pożądane w kluczowych sektorach zaawansowanych i ekologicznych technologii o dużym potencjale wzrostu i zatrudnienia. Działania na rzecz poprawy funkcjonowania rynku wewnętrznego koncentrują się na wspieraniu przedsiębiorczości w odniesieniu do jednolitego rynku cyfrowego, ochrony praw własności intelektualnej oraz dalszego wsparcia internacjonalizacji małych i średnich przedsiębiorstw. Zwiększenie dostępu do kapitału ma zostać osiągnięte poprzez lepsze ukierunkowanie środków publicznych oraz eliminację przeszkód w zakresie przepływu środków prywatnych i ułatwienie przepływów transgranicznych. Konieczne jest także lepsze dopasowanie systemu edukacji do wymogów zmieniającego się przemysłu (COM (2012) 582 final).

Wątpliwość budzi oczywiście przyjmowanie nowego długookresowego programu rozwoju, skoro założenia i realizacja poprzedniego nie zostały osiągnięte. Bieżące wyzwania 
zmusiły jednak Europę do redefinicji celów i instrumentów wspierających rozwój gospodarczy. Cele Strategii Lizbońskiej, czyli przekształcenie europejskiej gospodarki w najbardziej konkurencyjny i dynamiczny rynek - były bardzo ambitne, ale równocześnie trudne do osiągnięcia. Strategia Europa 2020 zwraca większą uwagę na sprawy społeczne i równowagę środowiskową. Uzasadnia także koordynację polityk gospodarczych w skali europejskiej. Trudno obecnie jednoznacznie ocenić, czy założenia Strategii są wystarczająco mocno osadzone w realiach oraz czy kraje członkowskie UE będą solidarnie realizowały jej postulaty.

\section{WNIOSKI}

Ostatnie dziesięciolecia charakteryzowały się znaczącymi zmianami w międzynarodowych strukturach produkcji i konkurencji, wywołanych m.in. procesami globalizacji i regionalizacji gospodarki światowej. Pojawienie się nowych potęg gospodarczych, takich jak Chiny czy Indie, zmiany technologiczne i klimatyczne oraz trendy demograficzne podkreślają potrzebę dostosowań strukturalnych. W krajach rozwiniętych zasoby i podaż pracy w sektorach pracochłonnych zostały przesunięte do tych charakteryzujących się występowaniem przewag konkurencyjnych. Takie przekształcenia strukturalne są pozytywne z perspektywy globalnej, mogą jednak rodzić szkodliwe skutki na poziomie lokalnym i regionalnym. Ponadto, tendencja przenoszenia miejsc pracy nie dotyczy współcześnie tylko tradycyjnej produkcji pracochłonnej, ale także zaawansowanej technologii. Zmiany te są dotkliwie odczuwalne na europejskim rynku pracy, dlatego wyjątkowo pożądanym efektem polityki staje się kreowanie nowych miejsc pracy i tworzenie warunków dla lepszego przepływu informacji między partnerami społecznymi. Wobec tych wyzwań potrzebne jest skuteczne podejście do polityki przemysłowej wspierające długofalowy wzrost i rozwój przemysłu. W celu utrzymania przewagi w branżach o dużej wartości dodanej niezbędne staje się wspieranie badań i promowanie innowacji oraz współpraca sektora badawczego z przemysłem. W literaturze przedmiotu powszechnie podkreśla się priorytetowe znaczenie potencjału ludzkiego, którego rola jest niezastąpiona we wprowadzaniu zmian technologicznych i organizacyjnych. Konieczne wydają się w tym kontekście zmiany w systemie i zakresie kształcenia oraz podnoszenie kwalifikacji pracowników i aktywizacja zawodowa. Promowane powinny być inicjatywy horyzontalne, skoncentrowane na znoszeniu barier administracyjnych i prawnych hamujących wzrost gospodarczy.

Niewątpliwie głównym motorem zmian strukturalnych w gospodarce pozostaje sektor prywatny, który dodatkowo generuje nowe miejsca pracy. Państwo odgrywa jednak równie ważną rolę w tworzeniu ram politycznych, które pozwalają korygować nieprawidłowości w funkcjonowaniu rynku oraz zachęcają do podejmowania przedsięwzięć innowacyjnych i wprowadzania zmian technologicznych. Taki zakres interwencji pomaga budować bardziej konkurencyjną i efektywną gospodarkę. W Europie coraz częściej podkreśla się potrzebę zintegrowanego podejścia do polityki przemysłowej, niemniej jednak kwestia praktycznej i skutecznej realizacji tych rekomendacji pozostaje otwarta. 


\section{Literatura / References}

Aiginger, K., Sieber, S. (2005). Towards a Renewal Industrial Policy in Europe. Project Lead Hannes Leo. WIFO. Pozyskano z: http://karl.aiginger.wifo.ac.at/.

Bianchi, P., Labory, S. (2006). International Handbook on Industrial Policy. Massachusetts: Edward Elgar Publishing Limited.

Bianchi, P., Labory, S. (2011). Industrial Policy after the Crisis. Seizing the Future. Cheltenham: Edward Elgar Publishing.

Breznitz, D. (2007). Innovation and the State. New Haven and London: Yale University Press.

European Commission (2004). Communication from the Commission of 20 April 2004: Fostering Structural Change: an Industrial Policy for an Enlarged Europe. COM(2004) 274 final.

European Commission (2012). Communication from the Commission to the Parliament, the Council, the European Economic and Social Committee and the Committee of the regions: A Stronger European industry for Growth and Economic Recovery. Industrial Policy Communication Update. $\operatorname{COM}(2012) 582$ final.

European Commission (2010). Communication from the Commission: Europe 2020. A Strategy for Smart, Sustainable and Inclusive Growth. COM(2010) 2020 final.

European Commission (2002). Communication of 11 December 2002 on: Industrial Policy in an enlarged Europe. $\mathrm{COM}(2002) 714$ final.

European Commission (2012). The EU in the Word. A Statistical Portrait. Luxembourg: Publications Office of the European Union.

Eurostat (2012, 29 listopada). Employment Growth and Activity Branches. Pozyskano z: http://appsso. eurostat.ec.europa.eu.

Eurostat (2012, 29 listopada). Industry Production Index. Pozyskano z: http://appsso.eurostat.ec.europa.eu.

Eurostat (2012, 29 listopada). Real GDP growth rate value. Pozyskano z: http://appsso.eurostat.ec.europa.eu.

Eurostat (2012, 29 listopada). Total high-tech trade in million euro and as a percentage of total (from 2007, SITC Rev. 4). Pozyskano z: http://appsso.eurostat.ec.europa.eu.

Eurostat (2012, 29 listopada). Total intramural R\&D expenditure (GERD) by sectors of performance. Pozyskano z: http://appsso.eurostat.ec.europa.eu.

Federal Ministry of Economics and Technology (2012, 20 grudnia). European Industrial Policy. Pozyskano z: www.bmwi.de.

Klamut, M. (2006). Polityka przemysłowa. W: B. Winiarski (red.), Polityka gospodarcza. Warszawa: PWN, 245-257.

Komisja Europejska (2010). Zintegrowana polityka przemysłowa w erze globalizacji. Konkurencyjność i zrównoważony rozwój na pierwszym planie. $\operatorname{KOM(2010)~} 614$.

Komisja Wspólnot Europejskich (2005). Komunikat Komisji: Wdrażanie wspólnotowego programu lizbońskiego: Ramy polityczne dla wzmocnienia przemystu UE - w kierunku bardziej zintegrowanego podejścia do polityki przemystowej. COM(2005) 474 końcowy.

Ministerstwo Gospodarki (2007). Koncepcja horyzontalnej polityki przemyslowej w Polsce. Pozyskano z: www.mg.gov.pl.

Owen, G. (2012, 2 grudnia). Industrial Policy In Europe Since the Second World War: What Has Benn Learnt. ECIPE OCCASIONAL PAPER, 1/2012. Pozyskano z: www.ecipe.org. 
Rifkin, J. (2012). Trzecia rewolucja przemystowa. Jak lateralny model władzy inspiruje całe pokolenie i zmienia oblicze świata. Katowice: Wydawnictwo Sonia Draga.

Stachowiak, K. (2009). Ewolucja przemysłu zaawansowanej technologii i sektora teleinformatycznego (ICT) w Finlandii. Prace Komisji Geografii Przemystu Polskiego Towarzystwa Geograficznego, $13,122-132$.

Tajani, A. (2012, 3 grudnia). A Stronger European Industry for Growth and Economic Recovery, Press Conference 10 October 2012. Pozyskano z: http://ec.europa.eu/enterprise/index_en.htm.

Talar, S. (2007). Determinanty konkurencyjności gospodarki Irlandii. W: T. Bernat (red.) Przedsiębiorstwo i państwo - wybrane problemy konkurencyjności. Szczecin: Uniwersytet Szczeciński, 247-258.

The Maastricht Treaty, Maastricht, 7 February 1992. OJ C 191 of 29.7.1992.

The Single European Act, Luxembourg, 17 February 1986. OJ L 169 of 29.6.1987.

Wade, R. (2010). After the Crisis: Industrial Policy and Developmental State in Low-Income Countries. Global Policy, 1-2, 150-161.

Marta Ulbrych, dr, Uniwersytet Ekonomiczny w Krakowie.

Zainteresowania naukowe autorki koncentrują się wokół procesów globalizacji i regionalizacji gospodarki światowej. W swych pracach badawczych analizuje zagadnienia z zakresu międzynarodowej integracji gospodarczej i jej praktycznej realizacji, roli polityki przemysłowej w erze globalizacji, przekształceń społeczno-ekonomicznych gospodarki Turcji oraz rozwoju regionalnego w Polsce.

Marta Ulbrych, Ph.D., Cracow University of Economics.

The author's research interests focus on the processes of globalization and regionalization of the world economy. She examines in her research work the issues of international economic integration and its practical implementation, the role of industrial policy in the globalization era, socio-economic transformation of the Turkish economy and regional development in Poland.

adres/address: Uniwersytet Ekonomiczny w Krakowie

ul. Rakowicka 27, 31-510 Kraków, Polska

e-mail: ulbrychm@uek.krakow.pl 